UDC 37.017 .4

DOI: $10.23951 / 2782-2575-2021-2-36-44$

\title{
THEORETICAL ASPECTS OF CIVIC POSITION FORMATION IN PEDAGOGICAL SCIENCE AND PRACTICE
}

\section{E. Yu. Plotnikova}

\section{Modern Technical University, Ryazan, Russian Federation}

The problems of the civic position formation of an individual are rooted in multiple factors. These include a challenging stage in the development of Russian society, social, cultural, economic, and political problems, rethinking the country's past, and unclear value references. All these factors can lead to moral disorientation and a loss of ideals.

At the present stage, the formation of civic position is an interesting subject of research for many scientists. They reveal the essence of Citizenship as a concept and describe civic position formation's psychological aspects. Moreover, citizenship is considered a social phenomenon, the formation of which depends on social relations and the organization of the educational process. During the last decade, there has been an increased interest in research on the problem of citizenship formation at an adolescent age.

In pedagogy, the following types of positions are distinguished: lifestyle, social, and internal. The similarity of the concepts of Internal Position and Attitude is emphasized, and it is explained that Attitude defines Position as a unified system of individual-personal relations between a person and their surrounding reality.

Objective and subjective factors under the influence of which a person's civic position is formed are also explained. The objective factors refer to socio-political conditions. Meanwhile, subjective factors refer to the interests of the individual, their needs, abilities, and values.

On this basis, the following components, which are most often highlighted by scientists in the study and generalization of a person's civic position, and contribution to its formation, are listed: cognitive (knowledge of citizenship, civic position, civil rights and responsibilities), motivational-valuable (a humanistic feature of a person's relationship to society, work, people and themselves, civic value orientations), and activity (ability to fulfill one's civil rights and duties, comply with social and legal standards, carry out socially significant activities for the public good). Three levels of formation of a person's civic position are distinguished and described (low, average, high).

The relationship and differences of such concepts as Patriotism, Citizenship, Civic Position, as well as Patriot and Citizen are emphasized, and their essence is revealed. By Patriotism, we mean the feeling of love and attachment to a country and alliance with other citizens who share the same sentiment to create a feeling of oneness among the people.

As part of the study of the civic position formation, the concept of Civic activity is touched upon, which is explained and classified by the following types: official (electoral process) and unofficial (participation in socially significant activities).

The manifestation forms of a person's civic position affecting their formation are outlined (passive, active, conformist (consumer), rebellious (protest), constructive). At the same time, emphasis is placed on an active civic position, in which society and the state are interested.

The conclusion clarifies the definition of Civic Position, which is explained as a system of positive value orientations that an individual may possess in relation to the state, law, civil society, themselves as an active citizen, carrying out socially important activities, and a focus on the public good.

* Original Russian language version of the article: Plotnikova E.Yu. Ponyatiye i sushchnost' grazhdanskoy pozitsii v pedagogike i psikhologii [Concept and Essence of the Civil Position in Pedagogy and Psychology]. Nauchno-pedagogicheskoye obozreniye - Pedagogical Review, 2019, vol. 6 (28), pp. 218-226. DOI: 10 23951/2307-6127-2019-6-218-226 
The analysis of the studied topic allows us to state its undoubted theoretical and practical significance since this problem is relevant and not fully solved at the present stage of the socio-political development of Russia.

Keywords: civic position; attitudes; inner position; social position; attitude; cognitive component; motivational-valuable component; activity component; citizenship; citizen; patriotism; patriot; civic activity; official civic activity, unofficial civic activity; active civic position.

Several modern trends in the socio-cultural sphere aggravate the problem of developing universal value orientations among students. Such trends include migration processes, virtual forms of intercultural communication, academic mobility, etc. Therefore, in pedagogical science and practice, the task of finding new content and effective forms of education for modern youth is relevant. In particular, civic position formation, which manifests itself in communication, social, and professional activity, is essential.

In this regard, teachers need to focus on training well-educated, socially active citizens with high moral standards. They should educate people ready to take civic responsibility for their actions and make responsible decisions, with awareness of the possible consequences. Therefore, the problem of civic positions formation among individuals in modern society is relevant.

At the moment, the question of the civic position formation is the research subject of such scientists as L.A. Baikova, A.M. Knyazev, T.I. Kobeleva, Y.V. Melnik, T.A. Miroshina, N.N. Perepecha, E.P. Strelnikova, T.A. Sukharev. Their works reveal the essence of the Civic Position concept. Due to scientists such as K.A. Abulhanova-Slavskaya, B.G. Ananiev, L.S. Vygotsky, V.N. Myasischev, S.L. Rubinstein psychological aspects of civic position formation have been put forward. In the works G.M. Andreeva, E.I. Isaev, I.S. Kon, A.B. Mudrik, B.D. Parygin, V.I. Slobodchikov, D.I. Feldstein civic position as a social phenomenon is revealed, the formation of which depends on social relations and the educational process organization. E.A. Bazaley, T.N. Balobanova, V.A. Grishko, T.I. Kobeleva, Y.I. Loyuk, N.V. Popovich, L.K. Fortova discovered and explored organizational and pedagogical conditions and ways of forming students' civic position. They also determined the criteria and the effectiveness indicators of civic position formation in the socio-cultural environment. During the last decade, interest in civic position formation research among adolescents has significantly increased. D.V. Kirillov [1] studied civic position formation among high school students in teaching humanities. T.I. Kobeleva [2] reviewed it by means of social design. K.I. Maslov [3] explored it in the university educational environment as a factor of students' civic position development. V.V. Strakhov [4] researched the formation of students' civic position at sports schools for children. E.P. Strelnikova [5] investigated it through extracurricular school work. A.F. Abzalov [6] examined pedagogical conditions of civic position formation in students of higher educational institutions.

In the Russian explanatory dictionaries by S.I. Ozhegov and I.D. Shvedova, the concept of Position has two definitions: "the principle underlying a person's behavior and actions" and "the position, place occupied by a person" [7].

I.S. Kohn [8] defines the concept of Social Position, which he characterizes as a person's place in the structure of social relations, in other words, his Social Role.

Modern scientists in the field of pedagogy noted the following Positions: lifestyle, social, internal. In the scientific studies of psychologists, the concept of Position is viewed through a position of a personality.

B.G. Ananyev [9] viewed the individual's position (social, economic, political) in society as social roles performed by a person depending on their position and political situation. According to 
Ananyev, such attitudes or roles performed by a person in certain situations represent exemplary behavior expected from any individual in given conditions. Ananyev also studied Position and Attitude as a person's Position, which characterizes the subjective, active side of the individual in the social structure. In other words, Position is an active expression of social status, the understanding of rights and duties, which reveals a person's status within society, a class, or a group.

When considering a Position as an activity component of a person's formation, L.I. Bozhovich [10] distinguished the terms Internal Position and External Position. Internal Position is formed by a person's previous experience, abilities, capacities, and emerging needs. It refers to the position a person occupies in society at a given moment and which they would like to occupy in the future. It is this Position that influences attitudes toward the outside world, other people, and themselves. Consequently, the Internal Position contributes to new personal qualities in the younger generation.

V.N. Myasishchev [11] pointed out the similarity of the terms Inner Position and Attitude. The scientist emphasized that Attitude describes Position as a unified system of individual relations of a personality with the surrounding reality. According to Myasishchev, a unified system formed in personality formation influences one's life experience. In his research, V.N. Myasischev distinguished three types of Relations: oneself, the people around, and the outside world. In addition, the author pointed out Social Relations and emphasized their necessity and importance. Since every person enters into these relations from birth and under their influence, one's social experience develops, and personality is formed.

When considering a person's attitudes as a Position, S.L. Rubinstein [12] pointed out the connection between a person's psyche and their activity, the signification of their wholeness and unity. Thanks to this, a person acquires the ability to define their position about social life.

A slightly different point of view was put forward by A.N. Leontiev [13]. He assumed that Position is not the result but the basis and forming factor of a person and their psyche. Consequently, personal development is progressed through comprehension of position through understanding. Thus, A.N. Leontiev explained the structure of an individual's development as a subject of social relations.

A.F. Shamich [14] believed that an individual's civic position is formed by combining objective and subjective factors. Objective factors include socio-political conditions such as political situation, the level of democracy, the economic level, the formation and development of social institutions of civil society, as well as the moral and psychological environment. The subjective factors, according to Shamich, are an individual's interests, needs, abilities, value orientations, inner world, spiritual wealth, level of self-awareness, worldview, motives of behavior, and their overall state of striving for socially significant activity.

In A.F. Abzalov, Position is defined in terms of meaningful activity, which is in turn expressed by the interrelation of intellectual, emotional, and active components concerning a specific object of reality. These components subsequently affect the behavior of the individual in specific social situations. Behavior, in turn, determines the development of social experience, in which a set of available skills, abilities, and knowledge plays a major role. Consequently, Abzalov considered Position as an evaluation of the political, economic, and social situation, in aspects of personal and state security, and distinguished three components within it: the personal, connected with the person readiness to self-actualization; socio-political, based on the willingness to serve for the benefit of one's homeland, to perform a civil duty and social, necessary for a person to implement both public and personal interests.

L.A. Eseleva [15] identified three components that are specific to the formation of a person's civic position: axiological (a person's position to the surrounding reality), behavioral (a person's 
desire to manifest behavioral attitudes), and activity-based (a person's willingness to act in the public interest).

K.I. Maslov considered three components of a person's civic position: cognitive, moral, and behavioral. The cognitive component characterizes a person's knowledge of citizenship concepts, civic position, civic activity, civil rights and duties, civil responsibility, and patriotism. The moral includes a person's attitude to oneself, other people, society, and the formation of civil value orientations. Lastly, the behavioral is based on a person's ability to perform their civil duties, bear civic responsibility, and be socially active.

Based on the study of A.F. Abzalov, V.V. Gavrilyuk, L.A. Eseleva, K.I. Maslov, we can conclude that researchers identify different criteria of a person's civic position formation. Upon analyzing the works on this problem, we can distinguish the following criteria: cognitive (knowledge of citizenship, civic position, civil rights, and responsibilities); motivational-valuable (humanistic orientation of a person's relationship to society, work, people, and oneself) and activity (ability to exercise their civil rights and responsibilities, carry out socially essential activities for the public good). These criteria are interconnected. Reducing any of these components will undoubtedly affect other components within the process, and hence, the formation level of a person's civic position as a whole.

Each of the formation indicators of a person's civic position has three levels: low (unstable and weak manifestation of civic behavior), medium (stable and positive civic behavior, but the active civic position is not always manifested), and high (stable and positive civic behavior, performance of socially significant activity, manifestation of active civic position, tolerance).

While analyzing theoretical approaches, K.I. Maslov singles out the following directions in the definition of Civic Position: homeland, state, civic duty, civic responsibility (V.I. Kozhokar, A.F. Nikitin, L.P. Razbegaeva, N.G. Suvorova, etc.), value attitudes to social reality (G.Y. Grevtseva, R.G. Gurova, V. Krysyak, B.T. Likhacheva, etc.), a person's active choice of one's social role (G.M. Kojaspirova, N.I. Eliasberg, etc.).

Nowadays, science gives a large number of definitions to the concept of Civic Position. According to the Universal Declaration of Human Rights: "Civic position is a responsible fulfillment of civic duty," and civic duty "is the requirements imposed on an individual in the form of obligations to the collective, social groups and society as a whole" [16].

A.F. Abzalov interprets the definition of Civic Position as an individual's civic worldview. Beliefs, rationale, understanding are interconnected with moral qualities, which, in turn, manifest themselves in actions, personal activity, and development of exemplary views and achieving goals.

T.I. Kobeleva defines Civic Position as an integrative system of a person's approach to their personality as a citizen, society, civil law, expressed in actions focusing on social and public benefits.

G.M. Kojaspirova [17] believes that Civic Position is a moral quality of a person that determines the conscious and active performance of duties to the state and society.

G.Ya. Grevtseva and T.P. Skrebtsova [18] distinguished three aspects of Civic Position: worldview, value, and culture. The worldview aspect includes knowledge, beliefs, and value orientations. The value aspect includes moral, political, and legal self-awareness. The cultural aspect is responsible for behavior, attitudes, and values. In addition, according to scientists, viewing Civic Position as a set of qualities of a person brings closer such terms as Civic Position and Citizenship. The latter is characterized as "an integral quality of man as a conscious and active citizen, formed and expressed in the following manifestations: high moral, knowledge of civil rights and responsibilities, willingness to work for the common good, determination and 
ability to defend the public interest, irreconcilability to anti-state manifestations, and ability to combine personal interests with public ones." This definition virtually eliminates the distinction between them.

The above analysis of the existing research shows that despite a diversity of existing definitions of the Civic Position concept, two main approaches to its interpretation can be identified. Certain researchers, E.P. Strelnikova, A.F. Shamich, for example, reveal the essence of Civic Position and define it as an integrative quality of a person. However, others, such as N.F. Kritskaya, A.M. Shalenov [19, 20], consider a person's Civic Position to be a set of moral, active, and social attitudes.

The concept of Civic Position is closely connected with Citizenship, which is why many scientists consider both concepts together when studying this problem.

According to A.M. Knyazev [21], Citizenship is a complex, multi-layered concept which has many characteristics. This term includes social activity and activity aimed at the benefit of a society and a state; manifestation of interest in the life of a society, a country and its history; observance of established norms of behavior and duties; performance of duty to a state and citizens; readiness and ability to perform civic duties; and, having a certain level of culture and knowledge related to a state or society, a system of civil relations.

G.N. Filonov [22] considered Citizenship as a set of personal qualities expressed in the performance of significant social tasks. The latter includes loyalty to the state and readiness to protect the interests of one's country, true faithfulness to the generally recognized principles, morals, and ethical values.

N.I. Eliasberg defined Citizenship as “a person's system of socially significant moral values that provide a sense of involvement in the fate of one's homeland and a readiness to take moral responsibility for its past, present, future together with active participation in the development of one's country in forms that meet moral and legal norms" [23].

Such terms as Patriotism, Citizenship, Citizen, Civic Position are closely connected in the history of a state. In the literature, these concepts are not separated. This forms objective difficulties in the comprehension of social events, development of scientific justifications, and construction of scientific conclusions. The concept of a "citizen" is interconnected with the concept of a Patriot, but they also have a number of distinctive features. A citizen knows their civil rights and duties and performs them. A patriot feels love for their homeland. On this basis, a citizen has moral and state values. A patriot has universal moral values.

According to D.V. Artyukhovich, "citizen" is considered as a legal definition: "a person consisting in a permanent political and legal connection with a state, which is expressed in mutual rights and obligations" [24].

A.M. Knyazev characterizes a citizen as a person who knows one's civil rights and duties, bears responsibility for one's actions, and is aware of the consequences of those actions. As a result, civil society is formed, which is a subject and object of the political structure of society.

According to A.F. Abzalov, positive dynamics in the development of a person's civic position can be achieved if the relationship Civic Position-Person is researched.

Based on the works included in this review, the following positions, connected with Personality as a concept and directly relating to the problem of its formation, are allocated. Firstly, in the conceptual idea - the primary basis of a person is determined (V.N. Myasischev). The works of B.G. Ananyev consider the essence of an individual as a "system-based quality of a person." In A.N. Leontiev and S.L. Rubinstein, a personality acts as an active person. In other words, the conditions of a subject's formation and development are manifested in its activity. 
A.N. Leontiev said that attitude to a state according to the motivational and demanding indicator is revealed by specific needs and interests in a personality. It is manifested as a desire and readiness to participate in socially significant activities.

E.P. Strelnikova singled out the emotional and evaluative indicators of relations and defined the conscious, indifferent, and rational attitude of an individual to the state's actions. In her opinion, this indicator is significant and necessary for forming a person's civic position.

When studying Civic Activity, T.I. Kobeleva emphasized that it begins not from the moment of a person's adulthood but their birth. From birth to maturity, a person participates in various activities, thereby entering into multiple relations with the state and society, accumulating everything that should characterize them as citizens. According to the researcher, "civic activity" can be conditionally divided into two types: official (electoral process, participation in referenda, or receiving a public office as a result of election or appointment) and unofficial (participation in various meetings, rallies, volunteer activities, defending their civil rights, views, interests).

The perception of oneself as a citizen of a country is understood as a person's attitude to civil rights, i.e., the presence of such rights, which only citizens of a particular country have. According to the Constitution of the Russian Federation [25], the rights of the citizen include the right to participate in the management of state affairs both directly, and through representatives, the right to elect and be elected to bodies of state power, and bodies of local self-government, as well as to participate in a referendum, state protection of human and civil rights and freedoms within the borders of the Russian Federation is guaranteed. Defense of the homeland is the duty and obligation of any citizen of the Russian Federation. The citizen performs military service under federal law.

Considering Civic Position as a combination of qualities of an individual, one should distinguish four components in its structure: legal, moral, social, and pedagogical.

From the legal standpoint, Civic Position was studied by K.I. Maslov. He found that it represents a conscious attitude of an individual to their position and their service as an active participant in civil activity in accordance with the legal position of the citizen.

The social side of Civic Position was studied by E.F. Seehr, I.S. Kohn [8, 26]. They noted that there is a certain interrelation between a specific person and civil society as a whole and between a particular citizen of the country and a citizen as a subject of social relations.

T.I. Kobeleva and M.V. Stepanova [2, 27] considered Civic Position in terms of morality. They said that it is an ideological and moral criterion of a person manifested in tolerance, empathy, altruism, selflessness, patriotism, diligence, and readiness to serve for the benefit of one's homeland. In addition, according to researchers, the personality must possess a number of moral values and attitudes. They are characterized by the priority of public benefit over personal gain, responsibility for one's actions and actions, as well as for their consequences.

The civic position of a person is manifested in various forms. It is possible to distinguish such forms as passive, active, conformist (consumer), rebellious (protest), or creative. Indeed, the state is interested in the formation of an active civic position of its citizens.

According to A.M. Knyazev, active citizenship reflects the strive to a civil partnership, which is based on the manifestation of one's abilities, respect, desire to understand another person, recognition of one's rights and freedoms, tolerance, and a desire to achieve unity of opinion to implement social cohesion.

I.A. Shalepo [28] characterized active citizenship as a conscious activity aimed at a society in which this individual socializes. That includes specific, deliberate actions and deeds of a personal and public nature, focused on developing civic values while maintaining a balance between personal and civic interests. 
The formation of an active civic position of a person includes an interest in socially significant activity, motivation and willingness to act, diligence, responsibility, awareness of personal significance and significance of each person, and the presence of organizational abilities.

A.G. Asmolov, A.M. Knyazev, T.A. Miroshina, G.N. Filonov [21, 22, 29, 30] have theoretically substantiated external and internal factors of forming a civic position. First of all, the formation of a person's civic position is associated with the objective state of society; the sociopolitical situation.

According to a number of academics such as A.F. Abzalov, T.N. Balobanova, N.N. Voloboeva, T.I. Kobeleva, A.A. Leontiev, T.A. Miroshina, V.N. Myasishchev, E.P. Strelnikova, N.E. Shchurkova $[2,5,6,11,13,31,30,32,33]$ the formation of the civic position of an individual includes the building of love for one's homeland, the need to work for the benefit of society, understanding and execution of civic duties, and awareness that one's actions and activities will affect the country as a whole.

Thus, Civic Position as a concept may be defined after the above study of the scientific works on the research topic, identifying the most significant relations objects for a person (state, law, society, citizen), and taking into account socio-political conditions. A civic position is a system of positive value attitudes that a person may hold towards the state, law, civil society, and themselves as an active citizen, by the execution of socially significant activities focused on the public good.

The formation of a persons' civic position is caused not only by subjective efforts of teachers but, above all, by the objective state of society, socio-political situation. The fundamental beliefs about the state are formed during puberty based on social experience gained at school, family, and society and subsequently developed throughout an individual's life. Thus, forming a person's civic position occurs based on personal qualities, such as civic knowledge, civic views, civic responsibility, civic behavior, civic activity, civic conviction, and civic duty. Based on that, one of the main tasks of forming a persons' civic position is the formation of moral patterns of behavior, patriotism, empathy, tolerance, and the need for an activity for the benefit of one's homeland. Awareness of civic duties, responsibility for the committed acts, and their consequences builds the basis for civic behavior and civic activities, thereby forming an active civic position.

The analysis of scientific works allows us to state the obvious theoretical and practical importance of the research conducted on the problem of the person's civic position formation. However, it should be noted that this problem is not fully resolved in the context of socio-cultural relations and the current stage of socio-political development of Russia in the second decade of the XXI century

\section{References}

1. Kirillov D.M. Formirovanie grazhdanskoy pozitsii starsheklassnikov v obuchenii gumanitarnym distsiplinam. Dis. kand. ped. nauk Formation of a civic stand of high school students in teaching humanities. Dis. cand. of ped. sci.]. Volgograd, 2005, 208 p. (in Russian).

2. Kobeleva T.I. Formirovanie grazhdanskoy pozitsii uchashchihsya starshih klassov sredstvami sotsial'nogo proektirovaniya. Dis. kand. ped. nauk Formation of a civil position of pupils of the senior classes by means of social design. Dis. cand. of ped. sci.]. Samara, 2006, 186 p. (in Russian).

3. Maslov K.I. Obrazovatel'naya sreda vuza kak faktor razvitiya grazhdanskoy pozitsii studentov. Dis. kand. ped. $n a u k$ [The educational environment of the university as a factor in the development of students' civil position. Dis. cand. of ped. sci.]. Krasnodar, 2008, 253 p. (in Russian).

4. Strakhov V.V. Stanovleniye i formirovaniye grazhdanskoy pozitsii uchashhihsya SDYUSHOR. Dis. kand. ped. nauk Formation and formation of a civic stand of students of the Sports School. Dis. cand. of ped. sci.]. Murmansk, 2006, 143 p. (in Russian). 
5. Strel'nikova E.P. Formirovanye grazhdanskoy pozitsii starsheklassnikov vo vneklassnoy rabote shkoly. Dis. kand. ped. nauk Formation of a civic position of high school students in extracurricular school work. Dis. cand. of ped. sci.]. Lipetsk, 2001, 267 p. (in Russian).

6. Abzalov A.F. Pedagogicheskiye usloviya formirovaniya grazhdanskoy pozitsii u studentov vuzov v protsesse izucheniya distsipliny "bezopasnost' zhiznedeyatel'nosti”. Dis. kand. ped. nauk [Pedagogical conditions for the formation of a civil position among university students in the process of studying the discipline "life safety". Dis. cand. of ped. sci.]. Ekaterinburg, 2006, 151 p. (in Russian).

7. Ozhegov S.I. i Shvedova I.D. Tolkovyy slovar' russkogo yazyka: 80000 slov i frazeologicheskih vyrazheniy. 4 izdaniye [Dictionary of the Russian language: 80000 words and phraseological expressions. 4 edition]. Moscow, Azbukovnik, 1997, 939 p. (in Russian).

8. Kon I.S. Psihologiya ranney yunosti: Kniga dlya uchitelya [Psychology of early adolescence: A book for the teacher]. Moscow, Enlightenment, 1989, 254 p. (in Russian).

9. Anan'ev B.G. Psihologiya i problemy chelovekoznaniya [Psychology and problems of human knowledge]. Moscow, Institute of Practical Psychology, 1996, 384 p. (in Russian).

10. Bozhovich L.I. Lichnost' $i$ ee formirovanie v detskom vozraste Personality and its formation in childhood]. St. Petersburg, Peter, 2008, 400 p. (in Russian).

11. Myasishchev V.N., Bodalev A.A. Psihologiya otnoshenij [Relationship psychology]. Moscow, MPSI; Voronezh, MODEK, 2004, 398 p. (in Russian).

12. Rubinshteyn S.L. Osnovy obshchey psihologii [Basics of general psychology]. St. Petersburg, Peter, 2015,713 p. (in Russian).

13. Leont'ev A.N. Deyatel'nost'. Soznanie. Lichnost': uchebnoe posobie [Activity Consciousness. Personality: study guide]. Moscow, Meaning, Academy, 2005, 352 p. (in Russian).

14. Shamich A.F. Vospitanie grazhdanskoy pozitsii studentov. Dis. kand. ped. nauk [education of a civil position of students. Dis. cand. of ped. sci.]. Ekaterinburg, 2002, 187 p. (in Russian).

15. Eseleva L.A. Sotsial'no-kul 'turnye metody formirovaniya grazhdanskoy pozitsii uchashchihsya Sankt-Peterburga (na primere molodezhi Nevskogo rayona). Avtoref. dis. kand. ped. nauk [Socio-cultural methods of forming a civic stand of students in St. Petersburg (on the example of young people in the Nevsky district). Abstract of thesis cand. of ped. sci.]. St. Petersburg, 2008, 19 p. (in Russian).

16. Vseobshchaya deklaratsiya prav cheloveka - rekomendovannyy dlya vseh stran-chlenov OON dokument, prinyatyy na tret'yey sessii General'noy Assamblei OON rezolyutsiya 217 A (III) ("Mezhdunarodnyj pakt o pravah cheloveka") ot 10 dekabrya 1948 goda [The Universal Declaration of Human Rights is a recommended document for all UN member states adopted at the third session of the UN General Assembly by resolution 217 A (III) ("International Covenant on Human Rights") of December 10, 1948] (in Russian).

17. Kodzhaspirova G.M. Kul'tura professional'nogo samoobrazovaniya pedagoga [Culture of professional selfeducation teacher]. Moscow, Gardariki, 1994, 146 p. (in Russian).

18. Grevtseva G.Y., Skrebtsova T.P. Grazhdanskoe vospitanie detet i podrostkov v uchrezhdeniyah sotsial'noy sfery: monografiya [Civic education of children and adolescents in social institutions: monograph]. Chelyabinsk, Cicero, 2011, 260 p. (in Russian).

19. Kritskaya N.F. Formirovanie grazhdanskoy pozitsii podrostka na osnove refleksii v protsesse izucheniya obshchestvennyh distsiplin. Dis. kand. ped. nauk Formation of the civic position of a teenager on the basis of reflection in the process of studying social disciplines: dissertation. Dis. cand. of ped. sci.]. Kirov, 2005, 214 p. (in Russian).

20. Shalenov A.M. Problema vospitaniya grazhdanstvennosti shkol'nikov v sovetskoy pedagogike 70-80-h godov. Avtoref. dis. kand. ped. nauk [The problem of civic education of schoolchildren in the Soviet pedagogy of the 70-80-s. Abstract of thesis cand. of ped. sci.]. Alma-Ata, 1991, 19 p. (in Russian).

21. Knyazev A.M. Grazhdanstvennost' lichnosti: monografiya [Citizenship of a person: monograph]. Moscow, Acad. Federal Border Service of Russia, 2003, 100 p. (in Russian).

22. Filonov G.N. Dialektika vospitaniya: uchebnoe posobie [Dialectics of education: a textbook]. Moscow, State Nauchn.-issled. Institute of Family and Education, 2007, 114 p. (in Russian).

23. Eliasberg N.I. Grazhdansko-pravovoe obrazovanie $i$ vospitatel'nyj potencial kursov istorii [Civil law education and educational potential of history courses]. St. Petersburg, Union, 2004, 51 p. (in Russian). 
24. Artyuhovich D.V. Grazhdanskaya aktivnost' lichnosti: social'no-filosofskij analiz. Dis. kand. filosof. nauk [Civic activity of the individual: socio-philosophical analysis. Dis. cand. philosoph. sci.]. Stavropol, 2002, 163 p. (in Russian).

25. Konstituciya Rossijskoj Federacii: ofic. tekst [Constitution of the Russian Federation: official. text]. Moscow, Marketing, 2001, 39 p. (in Russian).

26. Zeer E.F. Psihologiya professional'nogo obrazovaniya: uchebnik dlya studentov vuzov [Psychology of vocational education: a textbook for university students]. Moscow, Academy, 2009, 377 p. (in Russian).

27. Stepanova M.V. Osobennosti differencirovannogo podhoda v sisteme razvivayushchego obucheniya. Dis. kand. ped. nauk [Features of the differentiated approach in the system of developmental education. Dis. cand. of ped. sci.]. St. Petersburg, 2000, 199 p. (in Russian).

28. Shalepo I.A. Formirovanie grazhdanskoj pozicii starsheklassnikov v uchebnoj deyatel'nosti Formation of the civic position of senior pupils in educational activities]. Yaroslavl, Yaroslavl Pedagogical Bulletin, 2013, vol. 2, no. 3, pp. 40-43. (in Russian).

29. Asmolov A.G. Lichnost'kak predmet psihologicheskogo issledovaniya: uchebnoe posobie Personality as a subject of psychological research: a textbook]. Moscow, Moscow University Publishing House, 1984, 105 p. (in Russian).

30. Miroshina T.A. Formirovanie grazhdanskoj pozicii studentov vuza. Dis. kand. ped. nauk [Formation of the civic position of university students. Dis. cand. of ped. sci.]. Kemerovo, 2009, 255 p. (in Russian).

31. Balobanova T.N. Formirovanie grazhdanskoj pozicii uchashchihsya v sociokul 'turnoj srede shkoly. Dis. kand. ped. nauk [The formation of the civic position of students in the socio-cultural environment of the school. Dis. cand. of ped. sci.]. Sankt-Peterburg, 2007, 164 p. (in Russian).

32. Voloboeva N.N. Social'no-pedagogicheskie usloviya stanovleniya aktivnoj grazhdanskoj pozicii podrostkov v sovremennoj shkole. Dis. kand. ped. nauk [Socio-pedagogical conditions for the formation of an active civic position of adolescents in a modern school. Dis. cand. of ped. sci.]. Omsk, 2008, 155 p. (in Russian).

33. Shchurkova N.E. Pedagogika. Vospitatel'naya deyatel'nost' pedagoga [Pedagogy. Educational activity of the teacher]. Moscow, Yurayt, 2017, 365 p. (in Russian).

Elena Yu. Plotnikova, Senior Lecturer. The autonomous non-profit organization of higher education "Modern Technical University" (Novoselov 35A street, Ryazan, Russian Federation, 390048).

E-mail: alenap85@mail.ru 